\title{
Escaping from a Combination of Liquidity Trap and Credit Crunch
}

\author{
FRANK HEINEMANN
}

CESIFO WORKING PAPER NO. 2450

CATEgORY 6: MONETARY Policy and InTERnATIONAL FinanCE

NOVEMBER 2008

An electronic version of the paper may be downloaded
- from the SSRN website: $\quad$ www.SSRN.com
- from the RePEc website:
- from the CESifo website: 


\title{
Escaping from a Combination of Liquidity Trap and Credit Crunch
}

\begin{abstract}
This brief exposition suggests that the Federal Reserve System temporarily guarantee a lower bound on stock prices in order to escape the current combination of liquidity trap and credit crunch. It shortly discusses reasons for this measure, consequences, and some alternatives. It is meant as a policy suggestion in case the recapitalization of banks, agreed upon in midOctober 2008, turns out to be insufficient for stabilizing financial markets and the downward spiral in asset prices resumes.
\end{abstract}

JEL Code: E52, E58, E31, E44, G21.

Keywords: financial crisis, monetary policy, liquidity trap, credit crunch, asset markets.

\author{
Frank Heinemann \\ Berlin Institute of Technology \\ Straße des 17. Juni 135 \\ 10623 Berlin \\ Germany \\ f.heinemann@ww.tu-berlin.de
}

First version: October 8, 2008

This version: October 20, 2008 


\section{Motivation}

From the collapse of Lehman Brothers on September 15 to the announcement of the recapitalization of European banks on October 13 and US banks on October 14, stock prices were falling by several percent per day. Currently, it seems that this downward trend has come to a halt. This brief exposition suggests measures that could be taken in case the current recapitalization of banks turns out to be insufficient and the downward spiral of asset prices resumes.

\section{Situation}

Private investors are liquidating all kinds of real-valued assets and are instead hoarding liquidity at banks considered safe due to government guarantees.

Banks are selling their shares and are calling in debts to minimize loses and save their remaining equity and to simply remain solvent. They are parking their liquidity at central banks and are not issuing new loans.

Monetary policy is currently ineffectual: interest rate cuts are not being passed on and the expansion of the money supply has also failed to influence credit terms.

We are in a credit crunch - albeit not for lack of liquidity in the banking sector, but rather due to banks' naked fear of having to write off more debts and, thereby, of endangering their own solvency.

As monetary policy can presently neither reduce market interest rates nor stimulate the issuance of private loans, we are, furthermore, in a liquidity trap. The novelty here is that this liquidity trap is occurring at markedly positive interest rates, whereas it appeared in Japan through the zero bound on nominal interest rates.

\section{A Pessimistic Forecast}

If the wholesale selling of stocks continues, the assets of banks and insurance companies will continue to be devalued until these institutes are insolvent.

- Banks and insurance companies may be nationalized as governments infuse these institutions with fresh capital in exchange for shares.

- This will be financed through the issuance of new government debt that will be accepted by markets as investors are fleeing to safe nominal assets.

- Should governments not be able to finance themselves on capital markets, due to a loss of confidence by the markets, they would still have access to a final recourse: the purchase of these government debts by central banks.

- Alternatively, central banks could prop up banks by recapitalizing them. Here, a lasting expansion of the money supply would be necessary.

The last two possibilities would inevitably lead to higher inflation. 


\section{Textbook Wisdom}

There are two ways out of a liquidity crisis:

1. An increase in government expenditures (fiscal policy). This is already being accomplished indirectly through the partial nationalization of the banking sector. Additional government expenditures to stimulate the demand for goods could reduce the consequences of the crisis for the real economy, but would likely lead to large distortions and inefficiencies. However, increased demand will not stimulate investment if banks do not provide loans. Therefore, multiplier effects fail to unfold.

2. Increasing inflation expectations. This would lead to a reduction in real interest rates even with constant nominal rates and normally would stimulate investment demand. In the current situation, however, the latter is unlikely, as investment demand is irrelevant for markets so long as banks are not issuing new loans.

Textbook wisdom on escaping a liquidity trap is unlikely to work in the current situation, because we are in the unique situation of a combination of a liquidity trap and a credit crunch.

\section{Downward spiral}

We are currently experiencing a downward spiral: banks are selling their assets to maintain their solvency. As all banks are acting analogously, this reduces the value of assets, evaporating banks' equity. Consequentially, banks are forced to sell even more assts. ${ }^{1}$ Private investors are also acting along the same pattern to limit their losses. Since October 13, there are signs that the downward spiral is coming to a halt. The following deliberations are meant as suggestions should the current recapitalization of banks turn out to be insufficient and the downward spiral resume.

\section{How does a downward spiral end?}

Real value underlies stocks and mortgages. The downward spiral leads to a negative price bubble as was last seen in 2002. The dividend returns then exceed the returns on fixed income instruments and the risk for long-run oriented investors becomes very small. Eventually, investors will shift their portfolios and take advantage of the depressed prices to enter the stock and real estate markets.

\section{When will the flow of capital turn around?}

It is inevitable that expectations of a future rise in prices eventually prevail over expectations of a continuation in price decreases. For this to happen, however, a significant disequilibrium would have to occur first.

\section{Theory}

\footnotetext{
${ }^{1}$ For a more elaborate descriptions of a downward spiral, see e.g. Adrian, T., and H.S. Shin (2008), Liquidity and Financial Cycles, BIS working paper No. 256.
} 
We are seeing a increasing (positive) bubble in fix-income investments, government bonds and other investments considered "safe". (As their nominal value provides the basis of measurement, this is equivalent to a negative bubble in real values.) Here, Abreu/Brunnermeier ${ }^{2}$ and Brunnermeier/Morgan ${ }^{3}$ are applicable: every market participant is aware of the mistaken valuation, the lack of common knowledge (CK), however, hinders the bubble's bursting. The turnaround in capital flows can be expedited by a common signal, a piece of information that provides the markets with common knowledge that investment in real-valued assets is worthwhile.

\section{What could such a signal look like?}

The coordinated lowering of target interest rates on October 8 was apparently not a sufficient signal; from theoretical research and experimental results regarding coordination games and bubbles, we know that a common signal has an impact on behavior and beliefs about others' behavior only when the signal by itself has an impact on expected payoffs.

That means:

1. A signal must change the relative return expectations even in the absence of immediate changes in behavior.

2. Due to the changes in return expectations, there is an increase in market participants' propensity to change their investment positions.

3. As the signal is CK, market participants expect that others will also change their positions.

4. Due to strategic complementarities, participants react more strongly to the signal than they would have solely due to 1 .

The coordinated lowering of interest rates did create CK, but failed to fulfill condition 1., as changes in central bank rates are currently ineffectual or are considered ineffectual by the markets.

A coordinated recapitalization of banks, as was decided during the week from October 13 to October 17, might not suffice, as banks have no interest in buying stocks or expand lending under current conditions. Although banks are required to expand lending to the real sector as a condition for recapitalization by the government, it is not yet clear, whether this condition will work in resolving the credit crunch and lead to the desired turnaround in market expectations.

\section{Concrete suggestions:}

A turnaround in the dynamics could be achieved by several signals:

1. Several large private investors whose actions garner sufficient attention invest their liquid funds in stocks. Warren Buffet already did something along these lines with his investment in Goldman Sachs. This was, though, only a recapitalization of one bank and, thusly, ineffectual. What would have been necessary was the purchase of a broader set of assets on a much larger scale. I do not think that private investors hold enough funds to invest on the necessary scale.

\footnotetext{
${ }^{2}$ Abreu, D. and M. Brunnermeier (2003), Bubbles and Crashes, Econometrica 71, 173-204.

${ }^{3}$ Brunnermeier, M., and J. Morgan (2005), Clock Games: Theory and Experiments, working paper.
} 
2. Sovereign wealth and pension funds engage in large-scale purchases of stocks. These funds, like private investors, have no interest in coordinating their purchases for the common good, as they would thereby ruin the bargains they would otherwise be able to get. If only in the interest of their investors, pension funds are not in a position to make coordinated purchases.

3. China uses its foreign exchange reserves to buy stocks on US markets and makes its intentions publicly known. One could also question China's interest in announcing its intentions, but China would be the hero of the US financial system if it were to succeed. It could, furthermore, increase its strategic holdings and finally get rid of its exposure to Dollar-denominated government bonds. It would be a realistic chance for China to participate in stock markets without provoking kneejerk political reactions. Thus far, however, China does not appear to be seriously involved in discussions.

4. The Fed could buy up the excess supply of stocks and guarantee a clearly defined lower bound for the major stock indices for a limited time. This could be easily achieved through the targeted purchase of market portfolios in exchange for cash (Concrete example: the backing of the S\&P 500 through the sharing of costs and acquired shares by the participating reserve banks).

5. A credible announcement by the Fed of inflationary policy for a limited time.

I will now concentrate on suggestions 4 and 5 and, in the end, recommend 4.

\section{Temporary guarantee of a lower bound on stock prices:}

I assume that the guarantee will be at a level that is clearly below the present value of expected future revenues (fundamental value). Thus, it should only be effective if there really is a negative bubble; and, in the long run, potential purchases are expected to be profitable.

Pros: The announcement alone should prevent further sales from occurring. The Fed would actually only need to engage in limited purchases in an initial period to ensure the credibility of their announcement. By eliminating the downward risk, the flow of capital would reverse immediately and prices would advance significantly past the announced lower bound.

Cons:A guaranteed lower bound creates moral hazard problems. Thus, any such guarantee must be temporary in nature.

Inflation expectations: As the expiration of the guarantee nears, there are three possible scenarios to consider:

1. The crisis has come to a halt. Stock prices are sufficiently above the announced lower bound, and the expiration date has no significant effect on the level (apart from some temporarily higher volatility).

2. The crisis has come to halt, but markets expect that the guarantee is still a binding restriction. Stock owners will sell to the Fed well before the expiration date and the Fed is forced to acquire a large amount of stocks.

3. The crisis continues up to the expiration date of the guarantee: In this case, the Fed may decide to extend the guarantee or let it expire and stand ready to acquire a large amount of stocks. 
If the Fed really is forced to buy a large amount of stocks, this will be conducted through openmarket operations, increasing the money supply, and, thereafter, increasing inflation. As there is an ex ante positive probability that one these negative scenarios realizes, inflation expectations should increase immediately after the credible announcement of such a guarantee.

To the extent that there is immediate action and a well-defined expiration date, the suggestion comes close to a foolproof way of escaping a liquidity trap in the spirit of Svensson (2003). ${ }^{4}$

Note, however, that in the period leading up to the expiration date, inflationary expectations will exceed actual inflation. According to textbook wisdom, this should have contractionary effects on the demand side and tend to rather raise savings. In the current situation, however, with a liquidity trap occurring simultaneously with a credit crunch, such reductions in demand will hardly affect GDP, because current GDP is restricted by credit, not by demand. This is the same reason why fiscal policy is unlikely to have multiplier effects (see above).

Long-term impact: this action would continue to create a moral hazard problem in the future, as market participants would expect that the systemic risk in future crises would be borne by the Fed. On the other hand, current actions aimed at refinancing and recapitalizing banks have the same effect - but even more, because they are directly aimed at helping those institutions that created systemic risk. The latter creates a bailout arbitrage in which institutions have an additional incentive to magnify systemic risk.

A guarantee of a lower bound on stock prices is appealing in comparison with the original Paulson plan of buying troubled assets from banks, as the former exploits market mechanisms for injecting equity into the banking sector. There is no asymmetry distorting relative prices and the moral hazard problem is limited to systemic risk. Buying troubled assets, instead, preferentially rewards those institutions that caused the crisis by accumulating these assets.

\section{Announced temporary increase in inflation targets:}

Pros: -A temporary increase in inflation targets is credible under current circumstances.

- If the downward spiral continues, an increase in inflation is already inevitable.

- Higher inflation expectations lead to a shift in real return expectations from fixed-income assets to stocks and real estate and make real assets more attractive in one fell swoop.

- A joint signal along these lines could serve to coordinate market participants’ portfolio realignments and, thereby, lead to a turnaround in the flow of capital. The turnaround would become self-propagating and continue until the negative exaggerations in stock markets have been corrected.

- As a large fraction of Dollar-denominated debt is held abroad, the associated burden (inflation tax) will be borne by foreigners.

\footnotetext{
${ }^{4}$ Svensson, L.E.O. (2003), Escaping from a Liquidity Trap and Deflation: The Foolproof Way and Others, Journal of Economic Perspectives 17, 145-166.
} 


\section{Cons-1: Consequences for monetary policy}

A temporarily higher inflation target must be accompanied by a monetary policy that actually delivers the increases in price levels associated with the changed target. This would create the credibility that will be necessary for the subsequent period of disinflation after the cessation of the temporary target. Additionally, undercutting inflation expectations would lead to contractionary effects in the real economy that would necessarily have to be avoided as they would otherwise lead to a strengthening of the recession that is already expected.

In the long run, markets would have to accept and price the possibility of inflation temporarily exceeding its target. This possibility would have to be weighted more or less with the probability of a systemic banking crisis (that will no longer be neglected in the future). This would lead to an inflation-risk premium on long-term debt obligations and would, above all, make financing government debt more costly. A higher inflation bias in the sense of Barro and Gordon (1983) ${ }^{5}$ is not likely though, as wage contracts generally have shorter maturities.

\section{Cons-2: Political consequences}

A temporarily higher inflation leads to a de facto one-time real devaluation of savings deposits. This places the burden of financing the financial crisis on those parties who were least responsible for its inception, including older people whose savings are to a larger extent invested in nominal bonds.

I cannot foretell what consequences this might have for politicians and decision makers. To me, it would not seem to be a popular way to solve the crisis.

\section{Conclusion}

I recommend policy 4:

In the event that the downward spiral in asset prices resumes, the Fed should agree to temporarily guarantee a clear lower bound for the S\&P 500. It should arrange the implementation of this guarantee through targeted purchases of market portfolios. This action should be carried out by open-market operations and financed by injecting cash.

The portfolios thusly acquired can be sold for profit at a later date, reducing inflationary pressure in the long run, or to repay the government debt that has already been accumulated in various bailouts.

\footnotetext{
${ }^{5}$ Barro, R.J., and D.B. Gordon (1983), A Positive Theory of Monetary policy in a Natural Rate Model, Journal of Political Economy 91, 589-610.
} 


\section{CESifo Working Paper Series}

for full list see www.cesifo-group.org/wp

(address: Poschingerstr. 5, 81679 Munich, Germany, office@cesifo.de)

2389 Carsten Hefeker and Blandine Zimmer, Uncertainty and Fiscal Policy in an Asymmetric Monetary Union, September 2008

2390 Jay Pil Choi and Byung-Cheol Kim, Net Neutrality and Investment Incentives, September 2008

2391 Marcel Gérard, Financing Bologna, the Internationally Mobile Students in European Higher Education, September 2008

2392 Annette Alstadsæter and Knut Reidar Wangen, Corporations' Choice of Tax Regime when Transition Costs are Small and Income Shifting Potential is Large, September 2008

2393 António Afonso and Christophe Rault, 3-Step Analysis of Public Finances Sustainability: the Case of the European Union, September 2008

2394 Betsey Stevenson and Justin Wolfers, Economic Growth and Subjective Well-Being: Reassessing the Easterlin Paradox, September 2008

2395 Bernhard Eckwert and Itzhak Zilcha, Private Investment in Higher Education: Comparing Alternative Funding Schemes, September 2008

2396 Øystein Foros, Hans Jarle Kind and Jan Yngve Sand, Slotting Allowances and Manufacturers' Retail Sales Effort, September 2008

2397 Mohammad Reza Farzanegan, Illegal Trade in the Iranian Economy: Evidence from a Structural Model, September 2008

2398 Olivier Bos, Charity Auctions for the Happy Few, September 2008

2399 Robert S. Chirinko and Debdulal Mallick, The Marginal Product of Capital: A Persistent International Puzzle, September 2008

2400 Ben D'Exelle and Arno Riedl, Elite Capture, Political Voice and Exclusion from Aid: An Experimental Study, September 2008

2401 Torben M. Andersen and Joydeep Bhattacharya, On Myopia as Rationale for Social Security, September 2008

2402 Fabienne Llense, French CEO Compensations: What is the Cost of a Mandatory Upper Limit?, September 2008

2403 Valentina Bosetti, Carlo Carraro, Alessandra Sgobbi and Massimo Tavoni, Delayed Action and Uncertain Targets. How Much Will Climate Policy Cost?, September 2008 
2404 Robert G. Chambers, Rolf Färe, Shawna Grosskopf and Michael Vardanyan, Generalized Quadratic Revenue Functions, September 2008

2405 Leonidas Enrique de la Rosa, Overconfidence in a Career-Concerns Setting, September 2008

2406 Marcus Drometer and Johannes Rincke, The Design of Political Institutions: Electoral Competition and the Choice of Ballot Access Restrictions in the United States, September 2008

2407 Markku Lanne and Helmut Lütkepohl, Stock Prices and Economic Fluctuations: A Markov Switching Structural Vector Autoregressive Analysis, September 2008

2408 Thomas L. Brewer, International Energy Technology Transfers for Climate Change Mitigations, September 2008

2409 Alexander Kemnitz, Native Welfare Losses from High Skilled Immigration, September 2008

2410 Xavier Vives, Strategic Supply Function Competition with Private Information, September 2008

2411 Fabio Padovano and Roberto Ricciuti, The Political Competition-Economic Performance Puzzle: Evidence from the OECD Countries and the Italian Regions, September 2008

2412 Joan Costa-Font and Mireia Jofre-Bonet, Body Image and Food Disorders: Evidence from a Sample of European Women, September 2008

2413 Thorsten Upmann, Labour Unions - To Unite or to Separate?, October 2008

2414 Sascha O. Becker and Ludger Woessmann, Luther and the Girls: Religious Denomination and the Female Education Gap in $19^{\text {th }}$ Century Prussia, October 2008

2415 Florian Englmaier and Stephen Leider, Contractual and Organizational Structure with Reciprocal Agents, October 2008

2416 Vittorio Daniele and Ugo Marani, Organized Crime and Foreign Direct Investment: The Italian Case, October 2008

2417 Valentina Bosetti, Carlo Carraro, Alessandra Sgobbi and Massimo Tavoni, Modelling Economic Impacts of Alternative International Climate Policy Architectures. A Quantitative and Comparative Assessment of Architectures for Agreement, October 2008

2418 Paul De Grauwe, Animal Spirits and Monetary Policy, October 2008

2419 Guglielmo Maria Caporale, Christophe Rault, Robert Sova and Anamaria Sova, On the Bilateral Trade Effects of Free Trade Agreements between the EU-15 and the CEEC-4 Countries, October 2008 
2420 Yin-Wong Cheung and Daniel Friedman, Speculative Attacks: A Laboratory Study in Continuous Time, October 2008

2421 Kamila Fialová and Ondřej Schneider, Labour Market Institutions and their Effect on Labour Market Performance in the New EU Member Countries, October 2008

2422 Alexander Ludwig and Michael Reiter, Sharing Demographic Risk - Who is Afraid of the Baby Bust?, October 2008

2423 Doina Maria Radulescu and Michael Stimmelmayr, The Welfare Loss from Differential Taxation of Sectors in Germany, October 2008

2424 Nikolaus Wolf, Was Germany ever United? Evidence from Intra- and International Trade 1885 - 1933, October 2008

2425 Bruno S. Frey, David A. Savage and Benno Torgler, Noblesse Oblige? Determinants of Survival in a Life and Death Situation, October 2008

2426 Giovanni Facchini, Peri Silva and Gerald Willmann, The Customs Union Issue: Why do we Observe so few of them?, October 2008

2427 Wido Geis, Silke Uebelmesser and Martin Werding, Why go to France or Germany, if you could as well go to the UK or the US? Selective Features of Immigration to four major OECD Countries, October 2008

2428 Geeta Kingdon and Francis Teal, Teacher Unions, Teacher Pay and Student Performance in India: A Pupil Fixed Effects Approach, October 2008

2429 Andreas Haufler and Marco Runkel, Firms' Financial Choices and Thin Capitalization Rules under Corporate Tax Competition, October 2008

2430 Matz Dahlberg, Heléne Lundqvist and Eva Mörk, Intergovernmental Grants and Bureaucratic Power, October 2008

2431 Alfons J. Weichenrieder and Tina Klautke, Taxes and the Efficiency Costs of Capital Distortions, October 2008

2432 Andreas Knabe and Ronnie Schöb, Minimum Wage Incidence: The Case for Germany, October 2008

2433 Kurt R. Brekke and Odd Rune Straume, Pharmaceutical Patents: Incentives for R\&D or Marketing?, October 2008

2434 Scott Alan Carson, Geography, Insolation, and Institutional Change in $19^{\text {th }}$ Century African-American and White Stature in Southern States, October 2008

2435 Emilia Del Bono and Daniela Vuri, Job Mobility and the Gender Wage Gap in Italy, October 2008 
2436 Marco Angrisani, Antonio Guarino, Steffen Huck and Nathan Larson, No-Trade in the Laboratory, October 2008

2437 Josse Delfgaauw and Robert Dur, Managerial Talent, Motivation, and Self-Selection into Public Management, October 2008

2438 Christian Bauer and Wolfgang Buchholz, How Changing Prudence and Risk Aversion Affect Optimal Saving, October 2008

2439 Erich Battistin, Clara Graziano and Bruno Parigi, Connections and Performance in Bankers' Turnover: Better Wed over the Mixen than over the Moor, October 2008

2440 Erkki Koskela and Panu Poutvaara, Flexible Outsourcing and the Impacts of Labour Taxation in European Welfare States, October 2008

2441 Marcelo Resende, Concentration and Market Size: Lower Bound Estimates for the Brazilian Industry, October 2008

2442 Giandomenico Piluso and Roberto Ricciuti, Fiscal Policy and the Banking System in Italy. Have Taxes, Public Spending and Banks been Procyclical in the Long-Run? October 2008

2443 Bruno S. Frey and Katja Rost, Do Rankings Reflect Research Quality?, October 2008

2444 Guglielmo Maria Caporale, Antoaneta Serguieva and Hao Wu, Financial Contagion: Evolutionary Optimisation of a Multinational Agent-Based Model, October 2008

2445 Valentina Bosetti, Carlo Carraro and Massimo Tavoni, Delayed Participation of Developing Countries to Climate Agreements: Should Action in the EU and US be Postponed?, October 2008

2446 Alexander Kovalenkov and Xavier Vives, Competitive Rational Expectations Equilibria without Apology, November 2008

2447 Thiess Buettner and Fédéric Holm-Hadulla, Cities in Fiscal Equalization, November 2008

2448 Harry H. Kelejian and Ingmar R. Prucha, Specification and Estimation of Spatial Autoregressive Models with Autoregressive and Heteroskedastic Disturbances, November 2008

2449 Jan Bouckaert, Hans Degryse and Thomas Provoost, Enhancing Market Power by Reducing Switching Costs, November 2008

2450 Frank Heinemann, Escaping from a Combination of Liquidity Trap and Credit Crunch, November 2008 